\title{
Reconsideration of International Tax Cooperation and Management from the Perspective of "Internet
}

\author{
Yuan Jiao \\ School of Public Finance and Management, Yunnan \\ University of Finance and Economics, Kunming, Yunnan \\ Province, China \\ 412114030@qq.com
}

\section{+ ’}

\begin{abstract}
International taxation management is an important part of global economic governance. Under the background of "Internet +", governments should size this opportunity, take the tax evasion issue as the guide, seize the "Internet +" technology dividend, and continuously improve the tax collection and management capabilities of various countries. Based on the BEPS action plan, this paper comprehensively reviews the action effectiveness and policy orientation of the developed and developing countries in the field of international taxation in recent years. Finally, this paper proposes that the path of international taxation cooperation and management under the "Internet +" background should be planned from the following dimensions: expand the international tax "friend circle" and strive to expand the new space for international tax cooperation; implement the domestic and international dual track of "Internet + taxation"; grasp the "golden key" of blockchain and innovate tax management mode.
\end{abstract}

Keywords - “Internet +"; International Tax Cooperation; Tax Management

\section{INTRODUCTION}

"Internet +" is a concept with unique Chinese characteristics, which can be traced back to Edward Yu's speech at the Analysis' 5th Mobile Internet Expo in November 2012. He first proposed the "Internet + " concept. In March 2015, Premier Li Keqiang first proposed the "Internet +" action plan in the government work report. Then, in September, the State Administration of Taxation issued the "Internet + tax" action plan, which marks the deep integration of Internet innovation and taxation work.

At present, it has become a global trend that the Internet technology revolution centered on "digitalization, networking and intelligentization" drives innovation and development in various fields of the economy and society. The international tax management is an important part of global economic governance. Whether governments can seize the opportunity of

\author{
Chen Xue* \\ School of Public Finance and Management, Yunnan \\ University of Finance and Economics, Kunming, Yunnan \\ Province, China \\ 1960630076@qq.com
}

the "Internet +" reform, jointly combat international tax evasion to continuously improve the tax collection and management capabilities of low-income countries, and strive to expand new space for international tax cooperation, all of which have aroused widespread concern in various countries. In 2013, OECD launched the "Action Plan for dealing with Tax Base Erosion and Profit Transfer (BEPS)" with the help of the Group of Twenty (G20) platform. On May 14, 2018, in the thematic conference on "Co-construction of the "The Belt and Road" Tax Coordination and Cooperation" held in Astana, Wang Jun (Director of the State Administration of Taxation of China) proposed that we should improve the long-term mechanism of tax cooperation, and jointly promote the "The Belt and Road" countries and regions to achieve win-win situation and share development. This marks the beginning of the joint efforts of all countries in the world to build the modernization process of the international tax system. When international tax collection and management meets the "Internet +", whether China can make extraordinary voices in the global taxation administration and put forward a new type of Chinese taxation governance program to realize the springboard upgrading of international tax cooperation and management, which will undoubtedly be of extraordinary significance.

The 21 st century is an information age with the "network" as the core. People rely on the Internet to form a variety of "Internet+". The existing literatures at home and abroad, mainly focus on the impact and reform of international tax cooperation and management in the context of network economy, and less concerned about the integration of "Internet+" and international taxation and its path exploration. In view of this, this paper aims to explore the reform path of a new round of international tax cooperation and management under the "Internet + " by sorting out the international practices and policies in recent years. 


\section{INTERNATIONAL TAX COOPERATION AND Management Practice: ACtion EFFECTIVEnESS AND POLICY ORIENTATION}

So far, no consensus has been reached on how to deal with the tax issue of the digital economy. However, since the OECD launched the BEPS project, countries around the world have been working to reform their domestic tax system to adapt to the new cross-border business model.

\section{A. International Tax Cooperation and Management Practices in Developed Countries: An Investigation Based on OECD Countries}

The OECD issued an Interactive Map that reflects the progress of international tax cooperation in 150 countries and regions. It shows the key indicators and achievements of OECD on international tax issues, including participation in the Global Forum on tax transparency and information exchange and the implementation of information exchange requirements, participation in multilateral Mutual Aid Convention in tax collection and management and the implementation of automatic exchange of information, participation in the BEPS inclusive framework and the implementation of its results, especially the progress of the four minimum standards. In recent years, the latest policies and practices of various countries in the field of international tax cooperation and management can be summarized as follows:

For Canada, at the 2017 CTF Conference, the Canadian Ministry of Finance stated that it would continue to carry out BEPS work, paying particular attention to the tax challenges of the digital economy. On March 28, 2018, Quebec's Finance Minister, Carlos Letian, released the province's budget bill from 2018 to 2019. The budget bill announced the implementation of a new designated registration system, one of which includes a digital property and services distribution platform (hereinafter referred to as "Digital platform"), which involves the designation of taxable supplies for intangible movable property or services received by Quebec consumers. These digital platforms control key elements of the transaction with specific Quebec consumers, such as bills, transaction terms and conditions, delivery terms, and so on. Taking into account a threshold value of $\$ 30,000$, it is not necessary to consider the value of the taxable goods provided by the non-resident supplier through the digital platform when calculating the service price of the non-resident supplier, as this part will be included when calculating the threshold value applicable to digital platform $[4]$.

For France, it has been considering introducing the idea of taxing the digital economy, levying corporate taxes on income generated by market countries and redefining digitization, which includes the gratuitous nature of the work done by Internet users. It proposed two digital taxes in 2015: one tax is based on sales or advertising revenue, the other tax is based on
First, the policy orientation of taxation issues on digital economic. Take British as an example, it proposed a "Profit Transfer Tax" as early as in the 2015 "Financial Act" and all profits transferred will be taxed at $25 \%$, because it focuses on large digital multinationals and is also known as the "Google tax"[1]. As far as Australia is concerned, it follows the UK to levy taxes on all aspects of the digital economy, and it issued a draft legislation in 2017 [2], in order to implement digitization, announcing that money will be regarded as the traditional currency form of GST (Goods and Services Tax). The legislation aims to avoid the abnormal situation of the twice collection of digital money: the first is the purchase of digital currency, followed by their uses. Further, Australia plans to impose a $10 \%$ GST on all low-value imported goods (LVIGs), including delivery costs, from July 1, 2018. LVIGs refer to Internet import products from overseas that Australian consumers purchased online or by telephone ordering, which are priced below AUD1000. At the same time, it pointed out that if the turnover of low priced goods that overseas suppliers sold to Australian consumers is up to or more than AUD75,000, it will be required to register the GST at the Australian Tax Bureau and pay the tax on a quarterly basis. In addition, the Australian Interior Ministry proposed that from July 1 this year, in addition to levying consumption tax on all goods purchased from overseas, a new surtax of 2 to 7 yuan will be levied on each imported parcel. Since then, the age of duty-free online shopping is getting far away [3].

user activity, data flow, or advertiser on data collection quantity [5].

For Italy, from 2013 to 2014, it debated the introduction of VAT in the digital economy. The implementation of this measure was postponed and then abolished. At present, Italy is discussing the amendment of the transfer pricing legislation and levying the withholding tax on the intermediate products, which is also known as the "network tax". The goal of the proposed transfer pricing legislation is to stipulate the use of assessment techniques other than cost-based indicators to determine the full price for evaluating digital transactions. Once the "internet tax" is accepted, a withholding tax will be levied, and the state of the Permanent Establishment (PE) will be modified by introducing a minimum threshold of income, and a cost test will be conducted for multinational companies with branches in Italy[6]. On March 16th, 2018, the OECD's "Interim report" reached a global consensus solution on the "tax challenge brought by digitalization": the tax management forum and inclusive framework will work together to develop practical tools and cooperation in the field of tax administration, in order to analyze the increasingly widespread tax evasion risks formed by "cryptocurrency" and "blockchain technology" and their possible countermeasures, including requiring the digital asset trading platforms and the third-party platforms to report actively, and allowing the regulatory authorities to obtain information on digital assets transactions such as encrypted currencies. 
Second, the policy guidance of the PE and profit attribution. As far as France is concerned, it proposes to attribute profits to the jurisdiction where the user's social media services are based on the destination principle rather than the place of production principle. In the case of Australia, the Australian Taxation Office (ATO) introduced the Diverted Profits Tax (DPT) on July 1, 2017, which stipulates that the profits that transnational corporations deliberately transfer from Australia will be implemented at $40 \%$ tax penalties. In addition, the ATO released the draft "Practice Compliance Guide PCG 2018/D2" on February 7, 2018, which lists the DPT stakeholders' participation framework to assist taxpayers in assessing the risk level of DPT[7]. In the case of Canada, the new budget bill, released in March 28, 2018, one of the consumer jurisdictions stipulates that the non-resident suppliers, which are registered on the basis of the new designated registration system, will not become registrants of the Quebec Sales Tax (QST) on E-commerce. The seventh BEPS' Action Plans are aimed at avoiding the PE. The report puts forward specific solutions such as revising the model of the agreement, including the amendments of agency-based PE, the exemptions of PE, dealing with the contracts and separation of activities. Further, the "Interim Report" issued by OECD in March 2018 provides additional guidance on the revision of the PE, the redefinition of preparatory or ancillary activities, the rearrangement on which profits should be attributed to PE, and the simplification of the administrative measures for profit attribution.

Third, the new bud of transfer pricing: the country-by-country $(\mathrm{CbC})$ report. In 1995, OECD issued the "Guide to Transfer Pricing for Transnational Corporations and Tax Authorities", a landmark event in the field of international taxation, which greatly promoted the transfer of pricing legislation in some countries. As far as foreign practice is concerned, on February 13, 2018, the ATO announced the new $\mathrm{CbC}$ Guidelines, which aims to combat tax avoidance through more comprehensive information exchange between countries. $\mathrm{CbC}$ enables countries to strengthen their cooperation in tax collection and management more closely, promote transnational corporations to enhance tax transparency, reduce tax-related risks, and make the business planning of transnational enterprises and the management of tax sources more reasonable. The transfer pricing tax system in Australia basically follows OECD's transfer pricing guidelines, but it can be seen from the rights given to the tax authorities to redefine transaction conditions that the transfer pricing tax system in Australia is more stringent. At the same time, with the implementation of OECD's BEPS Action Plan, transfer pricing has become a global hotspot. Under this background, Australian tax authorities will further strengthen the transfer pricing compliance management [8]. In addition, on February 23, 2018, the Inland Revenue Authority of Singapore (IRAS) announced the "Income Tax: Transfer Pricing Guidelines (5th Edition)".
In addition, there are two major forms for international double taxation, including unilateral legislative actions of various countries or bilateral or multilateral agreement between different countries, but it is more difficult to avoid double taxation through unilateral legislative actions. OECD stated that the terms of the Common Agreement Procedure (MAP) for tax treaties provide a mechanism to resolve such cross-border tax disputes [9]. The G20/OECD, based on BEPS project, proposes that national tax officials who deal with MAP should be separated from frontline tax auditors and make independent decisions. The proposals are aimed at strengthening the international expert groups in the MAP (including private sector tax advisors, former public officials, and experts from OECD countries), emphasizing that they should use MAP to reach consensus on general explanations that can be published, which not only involves the taxpayer's claim to double taxation, but also the double non-taxation issue [10]. On February 28, 2018, OECD and Brazil launched a joint project, the Cross-border Tax Rules Discrepancy Review Project.

\section{B. International Tax Cooperation and Management Practices in Developing Countries: An Investigation Based on China and India}

At the international taxation cooperation level, in terms of China, the State Administration of Taxation has established a cooperative relationship with 25 international organizations such as UN, OECD, and IMF, providing various bilingual international tax service points, websites, consultations, and forums for the for the countries along the "The Belt and Road", and continuously holding taxation seminars to help developing countries to improve their tax collection and management capabilities. From the first institutional document in 2017, the "BRICs Tax Cooperation Memorandum" to the "Member of 2019-2021 Cooperation Memorandum" signed by the Chinese and Dutch tax authorities in 2018, from the first Global Advanced Tax Forum (FTA) in 2016 invited Pakistani, Georgian and other non-FTA member economies to the International Tax Conference based on the theme of "The Belt and Road" tax cooperation for the first time in Astana in 2018. The introduction of this series of measures shows that China has more determination and abilities to establish the Platform for Collaboration on Tax (PCT) for developing countries along the "The Belt and Road". At the International Tax Conference in 2018, China proposed to build a long-term tax cooperation mechanism, establish a Tax Commissioners' regular meeting mechanism, and improve the tax agreement network and other measures, and continue to expand the scope and depth of the tax cooperation. In the case of India, in order to eliminate the erosion of the tax base, its government has adjusted its domestic tax law to align it with the OECD's BEPS Action Plan, including the implementation of multilateral investment agreements in India's income tax treaty network. Further, India signed the Multilateral Instrument (MLI) on June 7, 2017, which has reached an agreement with designated associations on the avoidance of double taxation to limit double taxation on 
non-resident companies and allow information exchange and recovery of income tax. On March 19, 2018, Hong Kong and India signed a comprehensive double taxation avoidance agreement (a comprehensive agreement), which mainly includes the following three aspects: First, the judgment of PE. We can identify the countries that have the right to levy taxes by signing such a bilateral agreement, and give the tax credit of the taxable enterprise in another country, so as to avoid double taxation. Second, it clearly defined the principle of taxation on capital gains tax. If a resident of one Contracting Party obtains proceeds from transferring the shares of A company, and more than fifty percent of the value of $\mathrm{A}$ company's assets is directly or indirectly from the real estate of another Contracting Party, the proceeds can be taxed on another Contracting Party. In addition, the upper limit for levying taxes on dividends, interest and royalties and technical service fees is specified (if the actual beneficiary is a Contracting Party's enterprise, it is not more than $5 \%$ of total dividends, $10 \%$ of the total interest, $10 \%$ of the total royalties and $10 \%$ of the total technical service fees). Third, it also provides tax relief arrangements. The interest withholding tax imposed by India on Hongkong residents will drop from $20 \%$ to $10 \%[11]$.

In the international tax administration, many countries have made detailed provisions on technical service fees and royalties etc. For example, on February 28, 2018, the Financial Secretary of Hong Kong, Chen Maobo, announced the Budget for 2018-2019 in the Legislative Council. The Budget covers a series of taxation and short-term relief measures to boost the economy. In order to attract more foreign investment, it plans to introduce the Regional Headquarters tax regime (RHQ) in Hong Kong[12]. With regard to the avoidance of double taxation and tax evasion, China and Kampuchea have signed an agreement, which stipulates that if the beneficiaries of the royalties, interest and dividends are the Contracting Party's residents, the tax shall not exceed $10 \%$ of the total amount. At the same time, China has been promoting international tax management into a professional development track, strengthening the training of international tax leader talents, setting up a major risk centralized response mechanism for cross-border tax sources and the mechanism of the national joint inspection of anti-tax avoidance, so as to provide a strong guarantee for the realization of international tax modernization.

In the case of India, the 2018 Budget proposes to incorporate the concept of digital PE into Indian domestic tax law, and the Indian Finance Act proposes the latest balanced tax. According to the digital tax legislation, the tax includes $6 \%$ surtax. If the company does not set up a permanent agency in India, it will levy on the online advertising services for foreign companies. At the same time, India plans to levy a $10 \%$ long-term capital gains tax on earnings achieved in the stock market before January 31, 2018, in order to reduce economic distortion and eliminate the erosion of the tax base. India has comprehensive transfer pricing regulations. Recently, the Central Board of Direct Taxes (CBDT) revised the tax rate of safe harbor, and taxpayers can sign an Appointment Pricing Agreement (APA) with CBDT to determine a fair transaction price.

In summary, in the context of the Internet, a series of measures adopted by each country actually represent a far-reaching change in the current international tax field. With the strengthening of international tax cooperation, the governments of all countries, including the OECD member countries, are committed to blocking the loopholes in international tax arbitrage caused by the separate governance of tax laws of various countries, that is, tax base erosion and profit transfer, and work together to realize the modernization of the international tax system.

III. The Path SELEction of International TAX COOPERATION AND MANAGEMENT FROM THE PERSPECTIVE OF "INTERNET+"

With the increasingly close economic interrelationships between countries and the increasing number of multinational corporations, combined with the significant differences in taxation systems and burden levels across countries, the use of legal loopholes to escape tax has become increasingly tricky, which has caused considerable loss in both developed and developing countries. It is difficult for tax administrations to prevent various kinds of tax evasion, tax avoidance, and tax evasion that occur outside their territorial jurisdiction. Therefore, they have to pay increasingly attention on strengthening international tax cooperation and management. In general, countries choose the following path for international tax cooperation and management.

\section{A. Establishing an International Tax Cooperation Platform and Expanding Tax Cooperation Circle}

The backward means of tax collection and management is an important cause of serious tax-base erosion in some countries. All countries should improve their tax collection and management capabilities through informatization construction. In addition, they should pay more attention to international tax cooperation and reconstruct international tax rules. In recent years, the international tax reform and the construction of tax administration capacity have become an important part of G20 Summit bulletins. On February 14-16, 2018, the first global meeting of the tax cooperation platform was held at the headquarters of the United Nations. The topics of the meeting included the development of tax collection and management capabilities and tax cooperation. The establishment of the PCT marks the deepening of practical cooperation between the four major international organizations (IMF, OECD, UN, and WB) in the field of tax administration capacity building.

With the introduction of initiatives such as the Common Reporting Standard (CRS), the BEPS project and the active participation of the UN Taxation Committee in the global financial account, an unprecedented era of international 
taxation cooperation is starting. All of these initiatives have created new opportunities for developing countries to participate in the discussion and formulation of international taxation policies. New opportunities are also provided for fully realizing the benefits of international tax cooperation.

The construction of tax collection and management capacity is the focus of developing countries in improving the taxation system. Developing countries have carried out diversified tax administration capacity building plans for tax development. With the help of the PCT, developing countries can now rely on more advanced and sophisticated tools to carry out tax collection and management activities such as BEPS projects. Despite this, due to the limitations of the tax administration capacity of developing countries, many challenges remain. China should work with international organizations and taxation departments of other countries to create a win-win international tax environment and accelerate the establishment of a global tax cooperation circle. With the gradual increase of countries participating in tax cooperation, it is necessary to establish an "international tax group". The four major international organizations IMF, OECD, UN, and WB, as administrators, manage the large group of international cooperation. Each member initiates can dialogue, share information resources, transport technology methods in the "group" to reduce the cost of collection and tax evasion, then to realize the Pareto optimality of tax revenues in various countries. We must not only give thumbs up to the "circle of friends" and attract overseas companies, but also active in the "circle" to continuously boost domestic enterprises "going out". While doing well the "small cakes" in various countries, we should also expand the global "big cake" and continue to expand the breadth and depth of tax cooperation.

\section{B. Realizing Domestic and International Implement of "Internet + Tax" Simultaneously}

With the deepening of economic globalization, new economies and new forms of business have had an impact on traditional international tax rules and tax administration in various countries. It is an effective way to improve the tax collection and management capabilities by using of "Internet + ". In recent years, China's tax departments have continuously innovated tax collection and management methods, and many areas have taken the lead in the world. The comprehensive development of the Golden Tax Phase III project in 2016, the comprehensive promotion of the new VAT invoice management system, and the "Internet + Tax" Action Plan have played important roles in improving China's tax information, prevention of risks, optimization of services, and supporting decision making. In 2017, China's State Administration of Taxation strengthened the coordinated supervision with various departments, strengthened joint punishment, and established a "black list" of tax violations. In 2018, the China's taxation systems will continue to improve the effectiveness of taxation management and services, deepen the Reform of "Discharge, Management and Services", and focus on optimizing the taxation business environment.

Looking to the future, we should draw on the "Internet + taxation" domestic action to realize the deep integration of "Internet + international taxation" and focus on the following two aspects. First, we should combine software and hardware, the application of emerging technologies and network thinking innovation. In the policy selection and implementation path of "Internet + International Taxation", we should be guided by the hardware construction of explicit results, while focusing on both hardware and software. In the field of international tax collection and administration, the application of emerging technologies plays a fundamental role, which is an inevitable choice to break the information asymmetry and data segmentation status, and to increase the viscosity of "electronics" and "taxes" in various countries. What's more, the tax officials also have the key values. The sensitive and active thinking of tax officials is the decisive force in the virtual society. Countries should try to establish Tax Commissioners' regular meeting mechanisms, attach importance to brainstorming discussions and exchanges, and build a team of international tax professionals with both network thinking and emerging skills. The second is to combine pilot exploration and promotion. Accelerate the construction of digital infrastructure, combine different national institutions and private enterprises, and promote the transition from spot trading destinations to the global e-commerce market, to explore a new path for "Chinese version" of international taxation cooperation and management.

\section{Holding Blockchain as a "Golden Key" and Innovating Tax Management Model}

Looking into the future, we should strengthen "blockchain + taxation control". Blockchain itself has the characteristics of "shared ledgers, consensus mechanisms, traceability, non-discriminatory, non-recoverable, wisdom contracts", which makes its application prospects in the international taxation field broad. In view of the reality of tax collection and management constraints, in the future, there is an urgent need to use emerging information management methods such as "blockchain + taxation control" based on big data and artificial intelligence to break the tax data islands and information gaps. Specifically, "blockchain +" international taxation control still needs to be planned from the following four aspects. First, build a "node network map" centered on taxpayers and a global "collaborative network relationship map" centered on the tax authorities of various countries, which ultimately builds a blockchain-based cloud invoice and cloud ledger system[13], to root out taxpayers' subjective risk of tax evasion. The second is to accelerate the construction of international taxation platforms and carry out technical exchanges and cooperation. Learn from the international open source community building and application model, strengthen cooperation through forum member units, build an open source 
community of international tax blockchain, and improve the safety and reliability of blockchain technology. It is recommended that large companies increase investment in R\&D and build a blockchain universal development platform to reduce the research and application costs of blockchain technology. At the same time, we should strengthen mutual communication and cooperation in core key technologies such as consensus mechanism, programmable contract, distributed storage and digital signature. Third, based on the taxpayer data, we should build a real-time risk identification and automatic warning model, a response and disciplinary mechanism to continuously improve the efficiency of international taxation. Fourth, speed up the establishment of international tax personnel training system. The tax specialties of key universities and colleges in various countries should introduce blockchain professional courses, establish international tax-related blockchain talent training bases, and strengthen the training of professional talents and high-end talents.

In addition, the transfer pricing tax system should be perfected in order to align with international practices. In view of the current stringent transfer pricing tax system, the rational management of internal transfer pricing is very important for multinational corporations to control tax risk and financial certainty. In order to realize the fair tax burden target and safeguard national rights and interests, China's transfer pricing tax system must be in line with international practice. Based on improving laws and regulations, we must begin to strengthen the implementation of laws and regulations so that the transfer pricing tax system will be comprehensive and efficient.

\section{ACKNOWLEDGEMENT}

This research is financially supported by Major Project of the National Social Science Foundation of China: Research on Tax Collection and Management Mode under the Background of "Internet + "(17ZDA053).

\section{REFERENCES}

[1] Julia Kollewe, Smirnoff owner Diageo to pay HMRC $£ 107 \mathrm{~m}$ in "Google tax crackdown" The Guardian[EB/OL]. [2017-05-11]. https://www.theguardian.com/business/2017/may/10/diageo-to-pay-reve nue-107m-in-google-tax-crackdown.

[2] Exposure Draft Legislation, Treasury Law Amendment (Measures for a later sitting) Bill 2017: GST treatment of digital currency, July 2017.

[3] KPMG. GST on low value imported goods -theory | KPMG | GLOBAL[EB/OL]. [2018-03-02]. https://home.kpmg.com/xx/en/home/insights/2018/03/gst-lvig-02-march -2018.html.

[4] KPMG. Highlights of the 2018-2019 Quebec Budget[EB/OL]. [2018-03-27].

https://assets.kpmg.com/content/dam/kpmg/ca/pdf/tnf/2018/ca-highlight s-of-the-2018-quebec-budget.pdf.

[5] M Bacache et.al. Taxation and the digital economy. A survey of theoretical models. [R],2015.

[6] Marco Allena, The Web Tax and Taxation of the Sharing Economy: Challenges for Italy[J] European Taxation, 2017(Volume 57), No. 7.

[7] KPMG. Diverted Profits Tax - the PCG is no longer MIA | KPMG | GLOBAL[EB/OL].

[2018-02-07].

https://www.ato.gov.au/General/New-legislation/In-detail/Direct-taxes /Income -tax-for-businesses/Diverted-Profits-Tax/
[8] KPMG column. KPMG Australia | Australian transfer pricing tax system summary - Australian Financial Network[EB/OL]. http://www.baomoney.com.au/kpmg/103856.jhtm]]

[9] OECD. OECD releases first peer reviews on implementation of BEPS minimum standards on improving tax dispute resolution mechanisms[EB/OL]. [2017-09-26]. http://www.oecd.org/ctp/dispute/

[10] Picciotto. Improving International Tax Dispute Settlement[J].Working Papers, 2016.

[11] KPMG. India: New income tax treaty signed with Hong Kong[EB/OL]. [2018-03-23].

https://home.kpmg.com/xx/en/home/insights/2018/03/tnf-india-new-inc ome-tax-treaty-signed-with-hong-kong.html

[12] KPMG. Hong Kong: Tax proposals in 2018-2019 budget[EB/OL]. [2018-03-01].

https://home.kpmg.com/xx/en/home/insights/2018/02/tnf-hong-kong-20 18-2019-budget.html

[13] Dong Zhixue, Zhang Yijun, Song Tao. Strengthening tax control, what can blockchain do? [J]. Tax Research, 2018(4). (In Chinese) 